\title{
Systematic study of Early Carboniferous palynological assemblages from the Llanos Orientales Basin, Colombia*
}

\author{
Hernando DUEÑAS ${ }^{1} \&$ Silvia N. CÉSARI ${ }^{2}$ \\ ${ }^{1}$ Academia Colombiana de Ciencias Exactas, Físicas y Naturales, Transversal 27 No. 39A-63 Bogotá, Colom- \\ bia. ${ }^{2}$ Museo Argentino de Cs. Naturales “B. Rivadavia”, Av. Angel Gallardo 470, \\ C1405DJR Buenos Aires, Argentina.
}

\begin{abstract}
This paper concerns the description of palynomorphs recovered from subsurface Early Carboniferous strata of the SM-4 well located in the Llanos Orientales Basin, Colombia. Thirty-two species of spores are recognized within the palynoflora. A new species is proposed: Spelaeotriletes colombianus Dueñas and Césari $s p$. nov. The assemblages were referred to the Tournaisian-Viséan by the presence of distinctive spore species with previous records in the Viséan and Tournaisian of Western Europe and Western Gondwana.
\end{abstract}

Key words: Lower Carboniferous, palynology, Colombia.

The Colombian Llanos Basin is a structural depression located in the eastern part of Colombia (Fig.1). The sedimentary sequence, which fills this depression, is divisible into three time units palynologically dated as Paleozoic, Cretaceous and Tertiary. Early Carboniferous strata found in interval 2010-2340 ft of the SM-4 well yielded assemblages dominated by terrestrial palynomorphs (Dueñas \& Césari, 2003). This is the only reference to Early Carboniferous sediments in the whole Llanos Basin. Stratigraphic data and miospore range distribution were discussed by Dueñas \& Césari (in press). The aim of this paper is to describe the Early Carboniferous palynological assemblages from the SM-4 well of the Los Llanos Orientales Basin, Colombia.

\section{MATERIAL AND METHODS}

Ten cutting samples from interval 2010$2340 \mathrm{ft}$ of the borehole SM-4 yielded miospores and acritarchs. Laboratory preparation followed the standard techniques using fluorhidric and hydrochloric acids. Sample residues were mounted on microscope slides in Canada balsam and all slides are stored at the National Core Library, Colombian Petroleum Institute, Bucaramanga (Colombia). The preservation is variable within the samples, but frequently is poor to moderate, and the palynomorphs are thermally

\footnotetext{
"Contribution to the IGCP Project 471
}

mature and display dark brown to black color. Miospore locations on slides are based on England Finder graticules.

\section{SYSTEMATIC}

Anteturma PROXIMEGERMINANTES Potonié, 1970

Turma TRILETES Reinsch emend. Dettman, 1963

Suprasubturma ACAVATITRILETES Dettman,1963

Subturma AZONOTRILETES Luber emend. Dettman, 1963

Infraturma LAEVIGATI Bennie \& Kidston emend. Potonié, 1956

Genus Calamospora Schopf, Wilson \& Bentall, 1944

Type species. Calamospora hartungiana Schopf, Wilson \& Bentall, 1944

\section{Calamospora liquida Kosanke, 1950 (Fig. 2 P)}

Description. Spores radial, trilete. Amb circular to subcircular. Laesurae simple, straight, extending three-quarters of spore radius. Exine laevigate, $1 \mu \mathrm{m}$ thick, usually with large compression folds.

Dimensions. Equatorial diameter: 65-75 $\mu \mathrm{m}$ (10 specimens).

Comparisons. Calamospora liquida is char- 


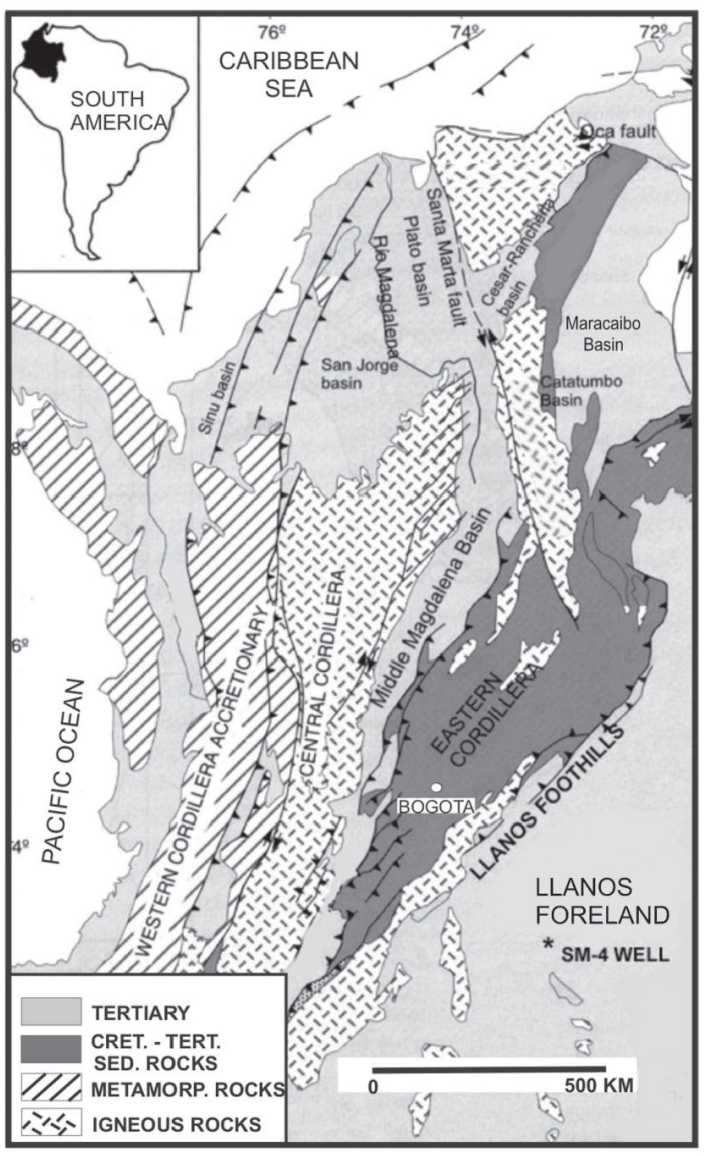

Fig. 1. Location map.

\section{Calamospora cf. C. nigrata (Naumova) Allen, 1965 \\ (Fig. $2 \mathrm{~N}$ )}

Description. Spores radial, trilete. Amb circular to subcircular. Laesurae simple, one-half to one-third of spore radius in length. Contact areas darkened. Exine laevigate, thin; folding very frequent.

Dimensions. 44-50 $\mu \mathrm{m}$ (5 specimens).

Comparisons. The present specimens are smaller than those described by Naumova (1953).

Previous records. This species was originally described from the Upper Devonian by Naumova (1953) and later recognized in the Tournaisian by Higgs et al. (1988).

Genus Leiotriletes (Loose) Potonié \& Kremp, 1954

Type species. Leiotriletes sphaerotriangulus

(Loose) Potonié \& Kremp, 1955

\section{Leiotriletes sp.}

(Fig. 2 B)

Description. Spores radial, trilete. Amb subtriangular with straight sides and rounded apices. Laesurae distinct, simple or with thin lips, extending up to three-quarters of the spore radius. Contact areas occasionally darkened. Exine laevigate, $1 \mu \mathrm{m}$ in thickness.

Dimensions. $35-56 \mu \mathrm{m}$ (8 specimens).

Comparisons. The specimens are treated at the generic level, because they are not clearly assignable to any described species.

Genus Punctatisporites Ibrahim emend.

the spore radius).

Previous records. This species has a widespread occurrence in Carboniferous strata.
Potonié \& Kremp, 1954
Type species. Punctatisporites punctatus

(Ibrahim) Ibrahim, 1933.

Fig. 2. A. Punctatisporites irrasus Hacquebard, 1957. Slide 2100-2130(2): W44, X750. B. Leiotriletes sp. Slide 2160-2190(2): V36/3, X750. C. Verrucosisporites irregularis Philips \& Clayton, 1980. Slide 2280-2310(1): K35/l. D, E. Anapiculatisporites concinnus Playford, 1962. Slides 2100-2130(2): M30/ 2; 2100-2130(1): X51/2, X 1000. F. Retusotriletes mirabilis (Neville) Playford, 1978. Slide 2100-2130(1): M 35/l, X750. G. Retusotriletes crassus Clayton et. al. 1980. Slide 2100-2130(2): F36/l, X750. H. Schopfites claviger Sullivan emend. Higgs et al., 1988. Slide 2100-2130(1): E41/4, X750. I. Anaplanisporites cf. A. denticulatus Sullivan, 1964. Slide 2130-2160(2): H39/4, X 750. J. Discernisporites micromanifestus (Hacquebard) Sabry \& Neves, 1971. Slide 2280-2310(2): H38/3, X750. K, O. Apiculirestusispora multiseta (Luber) Butterworth \& Spinner, 1967. Slides 2100-2130(2): T 45; 2070-2100(1) 137.5/10.2 X750. L. Raistrickia cf. R. clavata Hacquebard emend. Playford, 1964. Slide 2100-2130(2): N32, X1000. M. Verrucosisporites nitidus Playford, 1964. Slide 2220-2250(1): O49/3, X1000. N. Calamospora cf. C. ingrata (Naumova) Allen, 1965. Slide 2070-2100(1): M42, X750. P. Calamospora liquida Kosanke, 1950. Slide 2040-2070(1): C38/1, X750. Q. Retusotriletes incohatus Sullivan, 1964. Slide 2100-2130(1): L37/4, X750. R. Endosporites sp. Slide 2100-2130(1): B33, X750. 


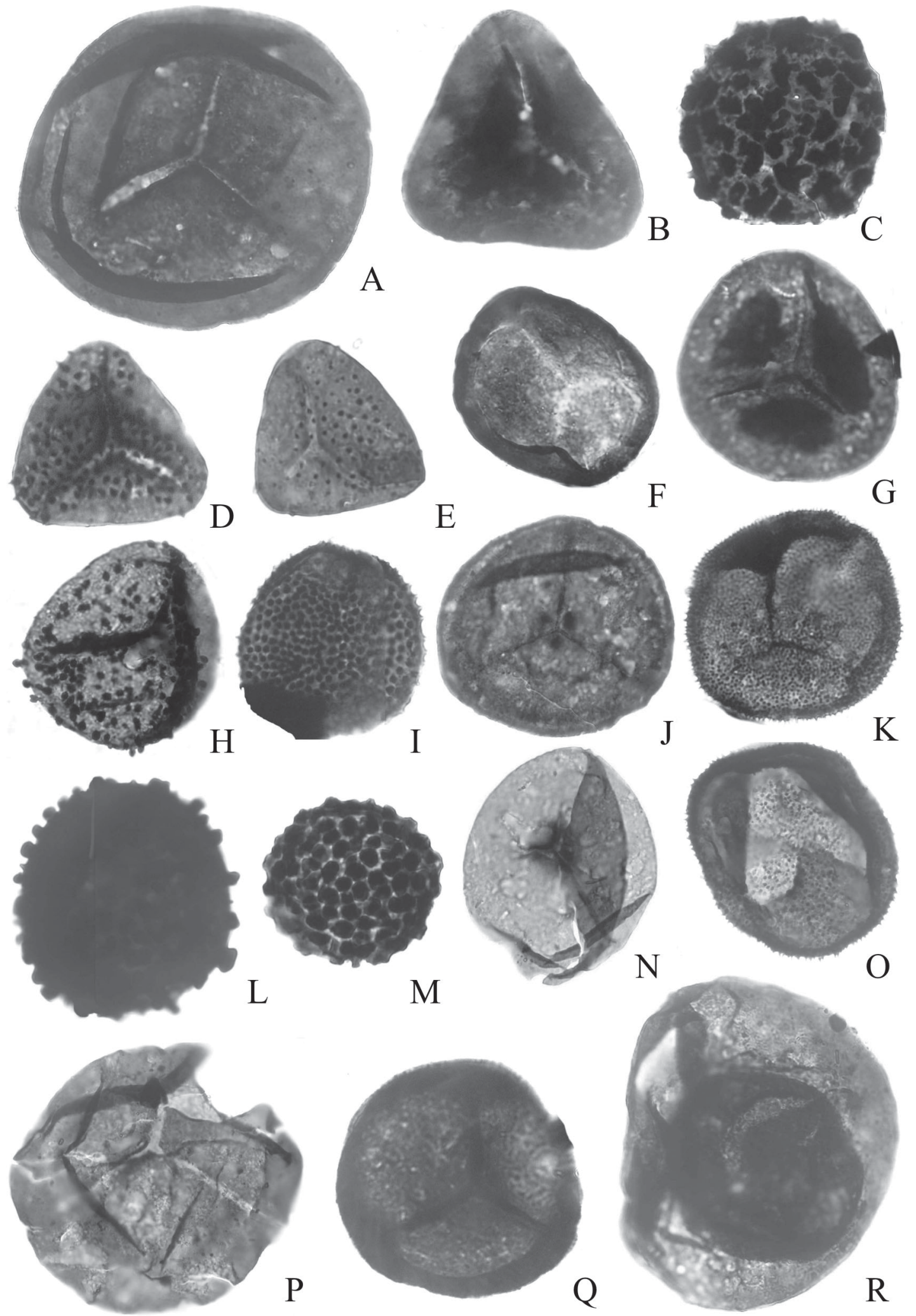




\section{Punctatisporites irrasus Hacquebard, 1957}

(Fig. 2 A)

Description. Spores radial, trilete. Amb subcircular. Laesurae distinct, occasionally with raised narrow lips, extending up to three quarters of the spore radius, frequently with dark intertectal areas. Exine laevigate to finely infragranulate, about $1 \mu \mathrm{m}$ thick. Compression folds common, particularly in the equatorial regions.

Dimensions. 42-72 $\mu \mathrm{m}$ (12 specimens).

Previous records. Punctatisporites irrasus is a characteristic Tournaisian species (Hacquebard, 1957; Sullivan, 1964; Clayton et al., 1977).

\section{Infraturma RETUSOTRILETI Streel, 1974}

Genus Retusotriletes Naumova emend. Streel, 1974

Type species. Retusotriletes simplex Naumova, 1953; by subsequent designation of Potonié (1958, p. 13).

Retusotriletes crassus Clayton in Clayton, Johnston, Sevastopulo \& Smith, 1980

(Fig. 2 G)

Description. Spores radial, trilete. Amb subcircular to subtriangular. Laesurae straight, simple, approximately four-fifths of the spore radius in length. The laesurae end in curvaturae perfectae which delimit the contact areas. Large thickened pads are present in the contact areas, separated from each other by radial zones of thin exine along the laesurae. Also thin exine separates the pads from the equatorial margin.

Dimensions. Diameter: 50-55 um (20 specimens).

Previous records. This species is recorded from the latest Strunian to the earliest Carboniferous from Europe (Clayton et al., 1980).

\section{Retusotriletes incohatus Sullivan, 1964} (Fig. 2 Q)

Description. Spores radial, trilete. Amb circular to subcircular. Laesurae distinct, usually extending for three quarters of spore radius, with fine lips. Contact areas depressed, delimited by perfect or imperfect curvaturae. Exine laevigate and darker outside the contact areas. Due to corrosion the specimens seem micropunctate.

Dimensions. 43-57 $\mu \mathrm{m}$ (10 specimens).

Previous records. This species originally described for the Tournaisian has been widely reported from late Famennian - early Viséan sequences (Clayton et al., 1977).
Retusotriletes mirabilis (Neville) Playford, 1978

(Fig. 2 F)

Description. Spores radial trilete. Amb convexly subtriangular to subcircular and rounded acute apices. Laesurae simple or with narrow lips extending four-fifths of spore radius. Contact areas well defined by perfect curvaturae. Exine laevigate.

Dimensions. Equatorial diameter: $48-54 \mu \mathrm{m}$ (10 specimens).

Comments. The specimens are in the lower extreme of the size range of the species.

Previous records. This is a characteristic species of the Viséan in Australia and England (Playford, 1991).

Infraturma APICULATI Bennie \& Kidston emend. Potonié, 1956

Subinfraturma NODATI Dybová \& Jachowicz, 1957

Genus Anapiculatisporites Potonié \& Kremp, 1954

Type species. Anapiculatisporites isselburgensis Potonié \& Kremp, 1954

Anapiculatisporites concinnus Playford, 1962 (Fig. 2 D, E)

Description. Spores radial, trilete. Amb subtriangular with rounded apices and convex to straight sides. Laesurae simple, length three-quarters of spore radius. Proximal surface laevigate. Distal surface sculptured with small coni, $1 \mu \mathrm{m}$ high, about 2-3 $\mu \mathrm{m}$ apart. They are characteristically absent at and around equatorial margin, particularly of interradial areas. Exine about $1 \mu \mathrm{m}$ thick.

Dimensions. 27-32 $\mu \mathrm{m}$ (12 specimens).

Remarks. Ravn (1991) emended the genus Spinositriletes Dybová and Jachowicz and included the species concinnus, but we consider more appropriate to maintain this species in the genus Anapiculatisporites.

Previous records. Mainly Viséan, worldwide (Playford, 1962; Smith \& Butterworth, 1967).

Genus Anaplanisporites Jansonius, 1962

Type species. Anaplanisporites telephorus (Klaus) Jansonius, 1962

\section{Anaplanisporites cf. A. denticulatus Sullivan, 1964 \\ (Fig. 2 I)}

Description. Spores radial, trilete. Amb rounded triangular to subcircular. Laesurae in- 
distinct, reaching almost the margin of the spore, simple or with thin lips. Sculpture of pointed cones with broad bases, $1 \mu \mathrm{m}$ wide and $1 \mu \mathrm{m}$ high, restricted to the distal and equatorial region, proximal exine laevigate. Cones arranged regularly in a quasi-concentric manner.

Dimensions. 29-40 $\mu \mathrm{m}$ (8 specimens).

Comparisons. The present specimens differ from the original in having smaller diameter and the sculpture projecting at the equatorial margin. Anaplanisporites delicatus Neves and Ioannides, 1974 differs in having curvaturae imperfectae and grana among the sculptural elements.

Genus Apiculiretusispora Streel 1964 Type species. Azonotriletes multisetus Luber, in Luber \& Waltz, 1938

\section{Apiculiretusispora multiseta (Luber)} Butterworth \& Spinner, 1967

(Fig. $2 \mathrm{~K}, \mathrm{O}$ )

Description. Spores radial, trilete. Amb circular to subcircular. Laesurae simple or with narrow lips, straight, usually with distinct curvaturae. Exine sculptured by spines with broad bases, approximately 1-2 $\mu \mathrm{m}$ high, densely distributed, less prominent in the contact areas.

Dimensions. 40-50 $\mu \mathrm{m}$ (30 specimens).

Comparisons. Apiculiretusispora fructicosa Higgs 1975, differs in being much larger in size and possessing more varied sculpture including coni, pila and short bacula. Apiculiretusispora microseta Ravn 1991, has smaller diameter and sculpture of fine coni less than $1 \mu \mathrm{m}$ wide at their bases.

Previous records. This species was originally described by Luber (in Luber \& Waltz, 1938) from the Lower Carboniferous of the Karaganda Basin and then recorded from many StrunianViséan assemblages.

\section{Subinfraturma BACULATI Dybová \& Jachowicz, 1957}

Genus Schopfites Kosanke 1950 Type species. Schopfites dimorphus Kosanke 1950

\section{Schopfites claviger Sullivan 1968} (Fig. $2 \mathrm{H}$ )

Description. Spores radial, trilete. Amb subcircular, usually preserved without any preferred proximo-distal orientation. Laesurae lipped reaching three quarters of spore radius. Exine sculptured with pila and bacula ca. $3 \mu \mathrm{m}$ long, characteristically outside contact areas, which are laevigate or bear sparse sculpture.

Dimensions. 47-50 $\mu \mathrm{m}$ (5 specimens)

Previous records. According to Playford (1991) this is a characteristic Early Carboniferous species in Northern and Southern Hemispheres.

Genus Raistrickia Schopf, Wilson \& Bentall emend. Potonié \& Kremp 1954

Type species. Raistrickia grovensis Schopf in Schopf, Wilson \& Bentall 1944

\section{Raistrickia cf. R. clavata Hacquebard emend. Playford 1964}

(Fig. $2 \mathrm{~L}$ )

Description. Spores radial trilete. Laesurae barely discernible. Amb subcircular to convexly subtriangular. Exine densely sculptured with discrete pilate projections, club- or mush-shaped, accompanied by verrucae and coni, up to $3 \mu \mathrm{m}$ high.

Dimensions. Equatorial diameter: $35-37 \mu \mathrm{m}$

Comparisons. The specimens are very dark not allowing a precise description of some morphological characters. Nevertheless, they seem co-specific with $R$. clavata by the varied sculpture.

Previous records. This species, originally described by Hacquebard (1957) from the Horton Group, has a widely distribution in Tournaisian and Viséan assemblages (Clayton et al. 1977).

\section{Subinfraturma VERRUCATI Dybová \& Jachowicz, 1957}

Genus Verrucosisporites Ibrahim emend. Smith \& Butterworth, 1967

Type species. Verrucosisporites verrucosus (Ibrahim) Ibrahim, 1933

Verrucosisporites nitidus Playford, 1964 (Fig. $2 \mathrm{M}$ )

Description. Spore trilete, amb circular to subcircular. Laesurae often indistinct, extending at least one-half of the spore radius. Exine sculptured by uniform and comprehensively distributed verrucae with rounded to rounded polygonal basal outlines and obtusely rounded lateral profiles. Verrucae $3 \mu \mathrm{m}$ in basal diameter and 2$\mu \mathrm{m}$ high.

Dimensions. Equatorial diameter: $30-50 \mu \mathrm{m}$ (11 specimens).

Previous records. This species has a worldwide distribution in the Lower Carboniferous inter- 
val (see Turnau et al., 1994, Playford, 1991, Melo \& Loboziak, 2003).

\section{Verrucosisporites irregularis Phillips \& Clayton, 1980 \\ (Fig. 2 C)}

Description. Spores radial, trilete. Amb subcircular. Laesurae simple, straight, length one half of spore radius. Exine sculptured with verrucae $1.5 \mu \mathrm{m}$ in diameter, subcircular to irregular in plan view. Usually the verrucae are basally fused forming short muri.

Dimensions. 40-45 $\mu \mathrm{m}$ (5 specimens).

Previous records. This species was described from Lower Carboniferous sediments (Phillips \& Clayton, 1980; Higgs et al., 1988).

Infraturma PATINATI Butterworth \& Williams 1958

Genus Cymbosporites Allen, 1965

Type species. Cymbosporites magnificus (Mc Gregor) Mc Gregor \& Camfield, 1982

\section{Cymbosporites acutus (Kedo) Byvsheva, 1985}

(Fig. 3 I)

\section{3}

Basionym. Archaeozonotriletes acutus Kedo,

Description. Spores radial, trilete. Amb subcircular to subtriangular. Laesurae indistinct, straight. Distal and equatorial regions sculptured with prominent wide and bulbous based spines. Elements discrete or fused in short ridges. Exine infragranulate and darker equatorially due to the sculpture. Spacing of sculptural elements variable, from densely to widely spaced; discrete to basally coalescent.

Dimensions. $35-58 \mu \mathrm{m}$ (6 specimens).

Comparisons. The cavate nature of this specific taxon was suggested by Higgs et al. (2000) who considered the generic assignment to Grandispora made by Byvsheva in 1980 was far more appropriate than her later assignment (Byvsheva, 1985) to the acamerate genus Cymbosporites. Nevertheless, Melo \& Loboziak (2003) maintained the proposal of Byvscheva (1985) and illustrated specimens similar to that here illustrated that seem acavate.

Previous records. This species has been recorded from the latest Famennian to Tournaisian in the northern hemisphere and the latest Famennian of Brazil (Melo \& Loboziak, 2003).

Genus Prolycospora Turnau, 1978

Type species. Prolycospora claytonii Turnau, 1978

Prolycospora rugulosa (Butterworth \& Spinner) Turnau, 1978

(Figs. $3 \mathrm{~A}, \mathrm{~B}, \mathrm{E}$ )

Description. Spores radial trilete, amb subtriangular to subcircular, margin finely crenulated. Laesurae simple, extending almost to the equator. Usually three distinct apical papillae are visible in the contact areas. Proximal surface microgranulose or punctate, distal surface finely rugulose. Cingulum tapering, $2-3 \mu \mathrm{m}$ wide.

Dimensions. 28-36 $\mu \mathrm{m}$ (25 specimens).

Comparisons. The specimens are very similar to the original ones and to those illustrated by Melo \& Loboziak (2003) from the Amazon Basin.

Previous records. This species, originally described from the Lower Carboniferous of England, has its first Late Viséan record in the Amazon Basin (Melo \& Loboziak, 2003).

\section{Subturma ZONOLAMINATITRILETES Smith \& Butterworth, 1967 \\ Infraturma CINGULICAVATI Smith \& Butterworth, 1967}

Genus Bascaudaspora Owens, 1983

Type species. Bascaudaspora canipa Owens, 1983.

Fig. 3. A, B, E. Prolycospora rugulosa (Butterworth \& Spinner) Turnau, 1978. Slides 2010-2040(1): 32/3; 2100-2130(1): E51/4; 2100-2130(1): N45, X1000. C, D. Vallatisporites splendens Staplin \& Jansonius, 1964. Slides 2130-2160(2): G42 ; 2100-2130(1): C46. F. Densosporites rarispinosus Playford, 1963. Slide 2100-2130(1): J48/4, X1000. G. Bascaudaspora submarginata (Playford) Higgs et al., 1988. Slide 2220-2250(1): W40/2, X750. H, K. Auroraspora macra Sullivan, 1968. Slide 20702100(1): T41/3, X1000. I. Cymbosporites acutus (Kedo) Byvscheva, 1985. Slide 2100-2130(2): R33/2, X750. J. Indotriradites daemonii Loboziak et al., 1999. Slide 2130-2160(1): W43, X750. L. Grandispora spiculifera Playford, 1976. Slide 2100-2130(2): J49/4, X750. M. Cristatisporites sp. Slide 2190-2220(1): C39, X750. N. Crassispora maculosa (Knox) Sullivan, 1964. Slide 2100-2130(1): Q36/4, X750. O. Indotriradites dolianitii (Daemon) Loboziak et al., 1999. Slide 2160-2190(1): V49, X750. P. Crassispora sp. Slide 2280-2310(1): Q34/4, X750. Q. Colatisporites decorus (B. \& V.) Williams in Neves et al., 1973. Slide 2100-2130(1): E39/4, X750. R. Auroraspora solisorta Hoffmeister, Staplin \& Malloy, 1955. Slide 2100-2130(2): J41/3, X750. 


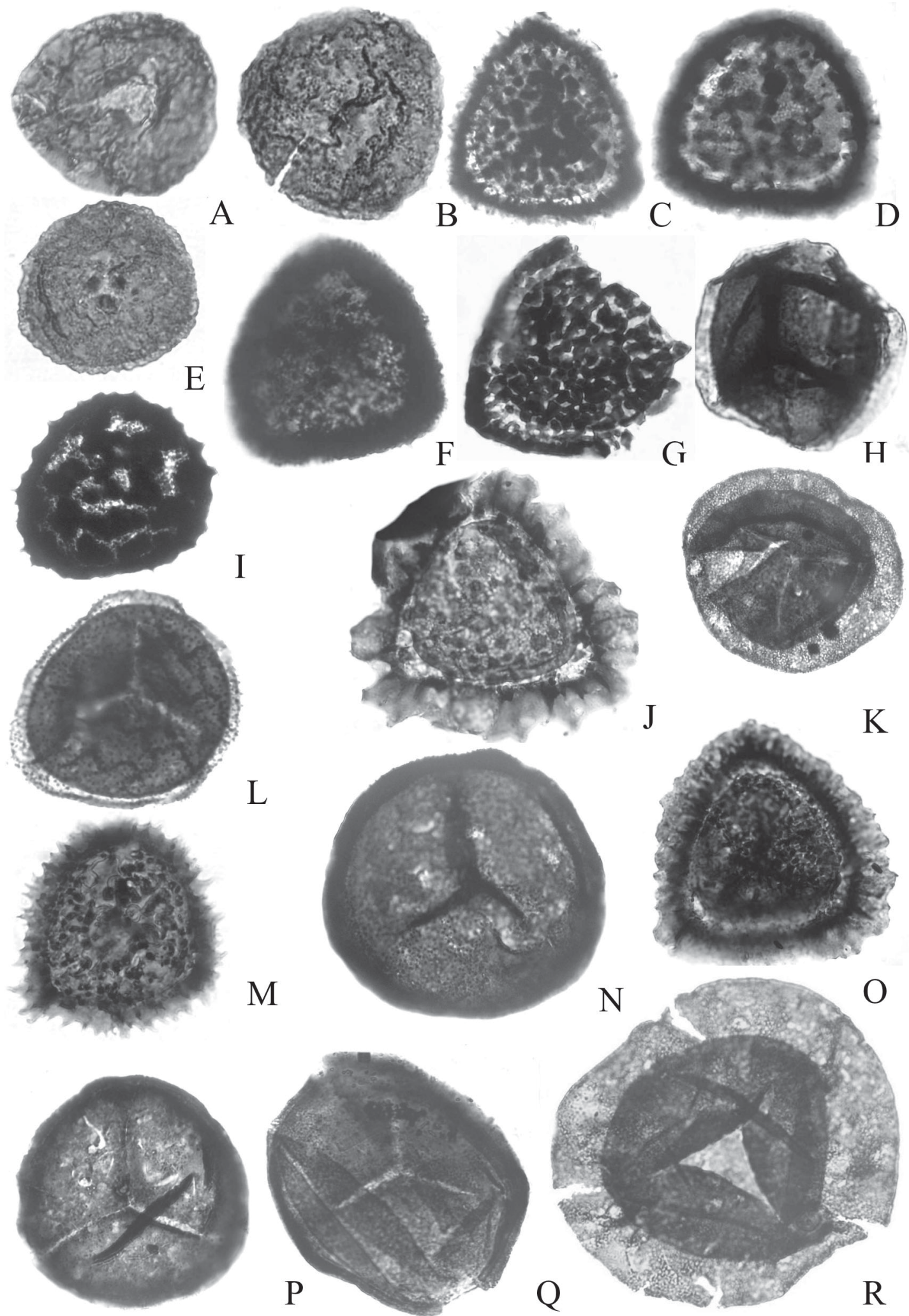




\section{Bascaudaspora submarginata (Playford) Higgs et al., 1988 \\ (Fig. $3 \mathrm{G}$ )}

Description. Spores radial, trilete, cavate. Amb subtriangular with convex sides and rounded apices. Laesurae indistinct, straight, extending almost to equator with narrow lips. Distal surface reticulate to rugulate with low, smooth, sinous muri which anastomose or terminate freely. Lumina are usually irregular in shape and size. Muri commonly beaded in appearance due to the presence of small rounded nodes. A distinct and continuous cingulum is present in equatorial region which appears darker and thicker. Proximal surface laevigate. Intexine thin, smooth, barely discernible, three quarters or more of the spore diameter.

Dimensions. 40-45 $\mu \mathrm{m}$ (7 specimens).

Comparisons. Owens (1983) defined Bascaudaspora as an acamerate spore, but its type species, B. canipa was described with separation of the exine layers. In accord to Higgs et al. (1988) is here considered that the genus accommodates variably camerate/acamerate spores. $B$. submarginata is characterized by a reticulate to rugulate distal surface, formed by narrow smooth sinuous muri and by a dark equatorial cingulum. The present specimens are slightly smaller than the original described by Playford (1964) but they are very similar to those described by Van der Zwan (1980, plate 29, figs. 1-3) as Dictyotriletes sp. A, considered a transitional form of his Dictyotriletes submarginatus morphon.

Previous records. This is a characteristic Strunian-Tournaisian species.

\section{Genus Cristatisporites Potonié and Kremp emend. Butterworth et al., 1964}

Type species: Cristatisporites indignabundus (Loose) Potonié \& Kremp, 1954.

\section{Cristatisporites sp.}

(Fig. $3 \mathrm{M}$ )

Description. Spores radial trilete, cavate. Amb convexly subtriangular, cingulizonate, margin conspicuously dentate. Exine bilayered, cavate. Intexine barely distinctive. Zona one-fourth of the spore radius. Proximal surface with reduced sculpture. Laesurae straight with fine lips, extending to the body margin. Distal surface sculptured with coni, verrucae 2-3ìm in basal width and 2 ìm high, sometimes basally coalescent. Zona sculptured by coni and spines up to $3 \mathrm{im}$ high with broad bases, discrete or basally coalescent to form cristae.
Dimensions: 48-54 $\mu \mathrm{m}$ (5 specimens).

Comparisons: The scarce number of well preserved specimens prevents a close comparison with known species of this genus, characterized by a great variability between representatives of the same species.

Genus Densosporites Berry emend. Butterworth, Jansonius, Smith \& Staplin, 1964 Type species. Densosporites covensis Berry, 1937

Densosporites rarispinosus Playford, 1963 (Fig. $3 \mathrm{~F}$ )

Description. Spores radial, trilete. Amb subtriangular, with convex sides. Laesurae occasionally indistinct, straight, extending on to the cingulum, simple or with thin lips. Cingulum 5$10 \mu \mathrm{m}$ wide, darker in colour than body. Distal surface sculptured with sparsely distributed spines about $2 \mu \mathrm{m}$ high and subordinate small verrucae. Apart of this sculpture, exine infrapunctate or laevigate.

Dimensions. 35-47 $\mu \mathrm{m}$ (10 specimens).

Comparisons. Original specimens described by Playford (1963) differ only in having spines up to $6 \mu \mathrm{m}$.

Previous records. This species was originally described by Playford (1963) from the Lower Carboniferous of Spitsbergen.

Genus Indotriradites Tiwari emend. Foster, 1979

Type species. Indotriradites korbaensis Tiwari, 1964

\section{Indotriradites dolianitii (Daemon) \\ Loboziak, Melo, Playford \& Streel, 1999}

(Fig. 3 O)

Description. Spores radial, trilete, cavate. Amb subtriangular, convex sides, equatorial margin irregular. Laesurae extending to inner margin of zona, rays with narrow lips. Zona of more or less uniform width $(8-10 \mu \mathrm{m})$, with the inner margin darker. Distal surface more densely sculptured in the central area with bulbous-based elements bearing short spinae, usually basally coalescent. Inner margin of the zona with larger coni and spinae and the rest of the zona with scarce coni and spinae. Intexine distinct, laevigate, thin, slightly contracted from exoexine.

Dimensions. Equatorial diameter: $50-70 \mu \mathrm{m}$ (20 specimens).

Previous records. Indotriradites dolianitii is commonly restricted to the Lower Carboniferous. This species was recognized in the late Viséan 
Faro and Poti Formations in northern Brazil (Daemon, 1974, Loboziak et al., 1999, Melo \& Loboziak, 2003), in the Viséan of the Grand Erg occidental, Algerian Sahara (Lanzoni \& Magloire, 1969).

Indotriradites daemonii Loboziak, Melo, Playford \& Streel, 1999

(Fig. $3 \mathrm{~J}$ )

Description. Spores radial, trilete, cavate. Amb subtriangular, convex sides, equatorial margin usually undulose. Laesurae extending to inner margin of zona, occasionally with thin lips. Zona of more or less uniform width, with the inner margin darker. Distal surface sculptured with minute coni and spinae. Inner margin of the zona with larger coni and spinae. Intexine distinct, laevigate, thin.

Dimensions. Equatorial diameter: $50-60 \mu \mathrm{m}$ (10 specimens).

Previous records. Specimens of I. daemonii have been recorded from Viséan strata of North Africa and Brazil (Lanzoni \& Magloire, 1969; Ravn et al., 1994, Loboziak et al., 1999).

Genus Vallatisporites Hacquebard, 1957 Type species. Vallatisporites vallatus Hacquebard, 1957

\section{Vallatisporites splendens Staplin \& Jansonius, 1964 \\ (Figs. 3 C, D)}

Description. Spores radial, trilete, amb convexly triangular. Laesurae indistinct with narrow lips reaching the equatorial margin. Exine twolayered, cavate. Intexine laevigate, its outline in polar view conformable with the amb. Zona onefifth of total spore radius in width, with little or no equatorial thinning. Inner part of the zone, with uniserial row of internal vacuoles, delimiting equator of intexinal body as a light area. Sometimes, a slight thickening of the inner half of the remainder zona gives a bizonate appearance. Exoexine proximally laevigate, distally bearing galeae and verrucae $2 \mu \mathrm{m}$ wide and $2 \mu \mathrm{m}$ high, irregularly arranged and usually fused in irregular ridges and pads bearing scattered minute coni. Equatorial margin with sparse spines.

Dimensions. Equatorial diameter: $36-45 \mu \mathrm{m}$ (15 specimens).

Comparisons. Our specimens resemble $V$. splendens in all respects except for their smaller diameter. According to its original diagnosis $V$. verrucosus includes specimens with sculptural elements predominantly discrete.

Previous records. This species was reported from the Strunian of Canada, uppermost
Devonian and/or lower Tournaisian of western Russian Federation and lower and upper Viséan of Iran (see Playford \& Mc Gregor, 1993).

Infraturma CRASSITI Bharadwaj \& Venkatachala emend. Smith \& Butterworth, 1967

Genus Crassispora Bharadwaj emend. Sullivan, 1964

Type species. Crassispora kosankei Potonié \& Kremp emend. Bharadwaj, 1957

Crassispora maculosa (Knox) Sullivan, 1964 (Fig. $3 \mathrm{~N}$ )

Description. Spores radial, trilete. Amb subcircular to convexly subtriangular. Laesurae distinct, usually accompanied by well developed folds, length up to three quarter of spore radius. Exine thickened equatorially $(3-4 \mu \mathrm{m})$ and sculptured with discrete coni about $1 \mu \mathrm{m}$ high and rounded bases.

Dimensions. Equatorial diameter: 60-64 $\mu \mathrm{m}$ (10 specimens).

Comparisons. The specimens are slightly smaller than the usually described for the species. Lophotriletes coniferus Hughes \& Playford 1961 also resembles our specimens, but as suggested by Sullivan \& Marshall (1966), this species could be synonymous with $C$. maculosa.

Previous records. This species is known widely in Late Tournaisian to Namurian assemblages (Sullivan, 1964; Clayton et al., 1977).

\section{Crassispora sp.}

(Fig. 3 P)

Description. Spores radial trilete. Amb subcircular to roundly subtriangular. Laesurae with narrow lips, ending in curvaturae imperfectae. Exine thickened equatorially $(5 \mu \mathrm{m})$ and distally densely sculptured with minute coni; usually with one fold. Proximal face laevigate or with reduced sculpture.

Dimensions. Equatorial diameter 56-60 $\mu \mathrm{m}$ (8 specimens).

Comparisons. The specimens studied here differ from the known species of the genus in the very fine and dense distal sculpture.

\section{Suprasubturma PSEUDOSACCITITRILETES Richardson, 1965}

Infraturma MONOPSEUDOSACCITI Smith \& Butterworth, 1957

Genus Auroraspora Hoffmeister, Staplin \& Malloy, 1955 emend. Richardson, 1960 
Type species. Auroraspora solisortus Hoffmeister, Staplin \& Malloy, 1955

Auroraspora solisorta Hoffmeister, Staplin \& Malloy, 1955

(Fig. 3 R)

Description. Trilete cavate spores. Amb subcircular to convexly subtriangular. Laesurae simple, usually open, extending to the edge of the intexine. Intexinal body distinct, outline conformable with amb, with a radius approximately one half of that of the exoexine. Exoexine microgranulate to micropunctate, thin, usually with radial folds.

Dimensions. 50-77 $\mu \mathrm{m}$ (20 specimens).

Remarks. The described specimens have granulate exoexine as well as the original specimens described by Hoffmeister et al. (1955). A. macra Sullivan 1968 is very similar but has a more subtriangular amb with a ratio of diameter of inner body to total spore diameter about three quarters (Van der Zwan, 1980).

Previous records. Latest Devonian?- ViséanNamurian sediments of North America, Europe, North Africa, Northwestern Australia and the Brazilian Amazon Basin (Hoffmeister et al., 1955; Streel \& Traverse, 1978; Bertelsen, 1978; Clayton et al., 1977; Turnau, 1978; Massa et al. 1980; Playford \& Satterthwait, 1988; Melo \& Loboziak, 2003).

\section{Auroraspora macra Sullivan, 1968}

(Fig. $3 \mathrm{H}$ )

Description. Spores radial, trilete, cavate. Amb subcircular to subtriangular. Laesurae simple or lipped extending up to the inner body margin. Intexine laevigate, slightly detached from the outer layer. Exoexine with spongeous infrastructure, frequently folded.

Dimension. 35-49 $\mu \mathrm{m}$ (10 specimens).

Previous records. According to Clayton et al. (1977), the last occurrence of this spore is in the Tournaisian.

Genus Colatisporites Williams in Neves et al., 1973

Colatisporites decorus (Bharadwaj \& Venkatachala) Williams in Neves et al. 1973 (Fig. 3 Q)

Description. Spores radial, trilete, cavate. Amb subcircular. Ratio of diameter inner body to total spore diameter about 9/10. Laesurae dis- tinct, simple or labrate, extending up to three quarters of the spore radius. Intexine laevigate, thin. Exoexine with spongeous infrastructure, frequently sculptured with small grana and folded.

Dimensions. Equatorial diameter: 50-64 $\mu \mathrm{m}$ (10 specimens).

Previous records. This species is characteristic of Tournaisian-Westphalian B of the northern hemisphere assemblages. It also occurs in late Tournaisian and late Viséan palynofloras of northern Brazilian basins (Melo \& Loboziak, 2003).

Genus Discernisporites Neves emend. Neves \& Owens, 1966

Type species. Discernisporites irregularis Neves, 1958.

\section{Discernisporites micromanifestus \\ (Hacquebard) Sabry \& Neves, 1971}

(Fig. $2 \mathrm{~J}$ )

Description. Spores radial, trilete, cavate. Amb convexly triangular. Laesurae distinct, with narrow lips extending to the margin of the spore; apical papillae occasionally present in the intertectal areas. Intexine distinct, laevigate, outline conformable with the amb, diameter approximately four fifths of the miospore diameter. Exoexine thin, finely granulate.

Dimensions. 50-60 $\mu \mathrm{m}$ (5 specimens).

Previos records. Discernisporites micromanifestus is known widely in assemblages of the Late Devonian-Namurian interval (Playford, 1991).

Genus Endosporites Wilson \& Coe ex Schopf, Wilson \& Bentall, 1944

Type Species. Endosporites ornatus Wilson \& Coe 1940.

\section{Endosporites sp.}

(Fig. 2 R)

Description. Spores radial, trilete, cavate. Amb subcircular to oval. Laesurae distinct, simple, extending up to three quarters of the intexinal body radius. Intexinal body distinct, laevigate, subcircular, eccentric, approximately one half of the miospore diameter. Exoexine thin, laevigate to infrapunctate, usually folded.

Dimensions. 67-80 $\mu \mathrm{m}$ (5 specimens)

Comparisons. The specimens resemble Diducites poljessicus (Kedo) emend. Van Veen, 1981 but do not have the two-layered exoexine. 

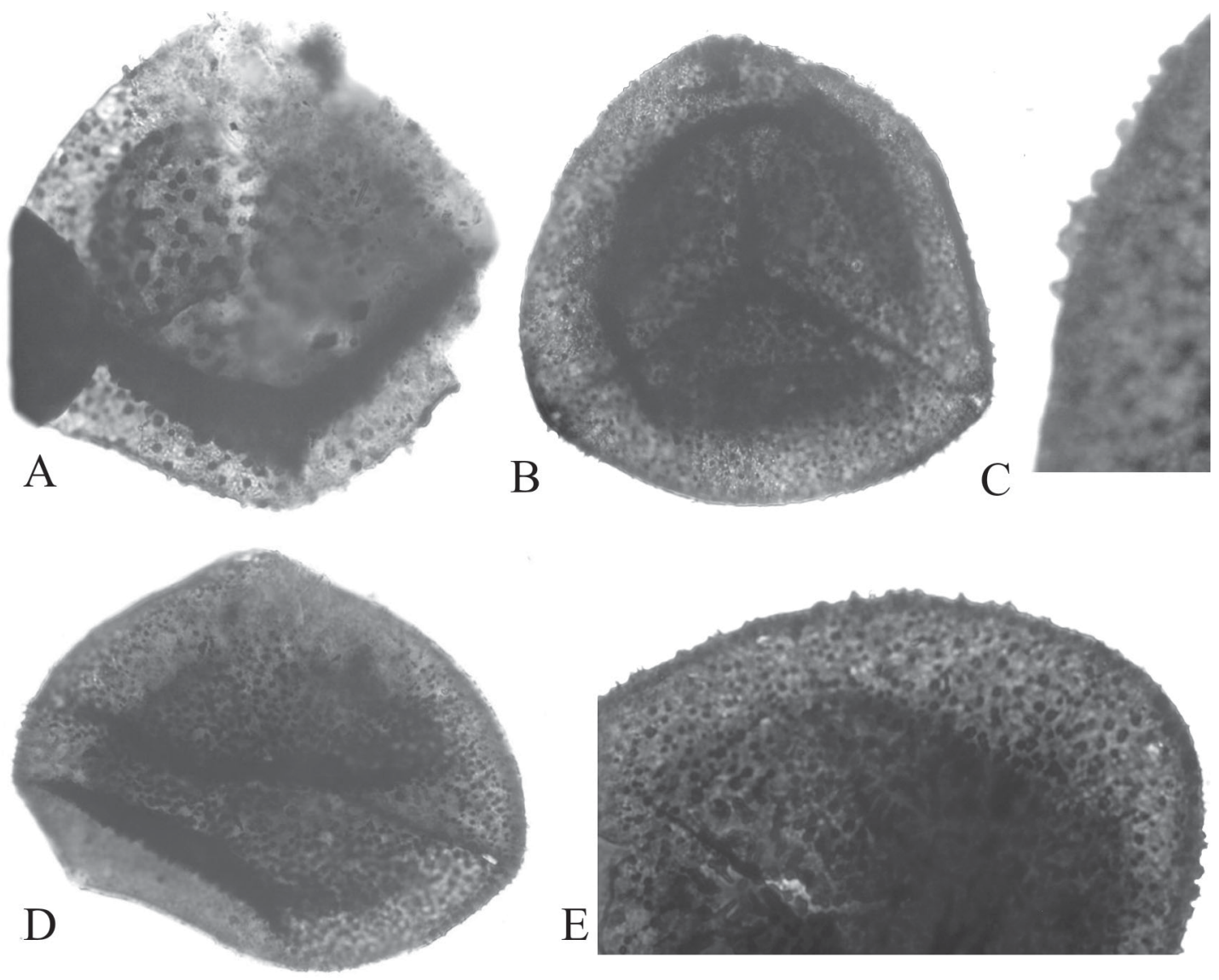

Fig. 4. A. Spelaeotriletes pretiosus (Playford) Utting, 1987. Slide 2160-2190(1): H35, X750. B, C, D, E. Spelaeotriletes colombianus sp. nov. B, Holotype, 20140-2070(1): C40/2, X750. C, Detail of sculpture, X1500. D, 2040-2070(1) 141.4/18.5, X750. E. Detail of sculpture, X1500.

Genus Grandispora Hoffmeister, Staplin \& Malloy, 1955 emend. Mc Gregor, 1973

Type species. Grandispora spinosa Hoffmeister, Staplin \& Malloy, 1955

\section{Grandispora spiculifera Playford, 1976} (Fig. 3 L)

Description. Spores radial, trilete, cavate. Amb circular to subcircular. Laesurae distinct, simple or with slight thickening extending up to intexinal margin. Exoexine with fine, dense, spinose sculpture reduced on the contact areas. Sculptural elements discrete, $1 \mu \mathrm{m}$ long and lesser than $1 \mu \mathrm{m}$ in basal diameter. Intexine distinct, outline more or less conformable with amb.

Dimensions. Equatorial diameter: $48-52 \mu \mathrm{m}$ (15 specimens)

Previous records. This species named an Early Carboniferous (Tournaisian) Assemblage palyno- zone in northwestern Australia (Playford, 1985). Also, G. spiculifera characterizes latest Devonianlate Viséan associations from the Amazon Basin (Melo \& Loboziak, 2003),

Genus Spelaeotriletes Neves \& Owens, 1966 Type species. Spelaeotriletes triangulus Neves \& Owens, 1966

\section{Spelaeotriletes pretiosus (Playford) Utting, 1987}

(Fig. 4 A)

Description. Spores radial, trilete, cavate. Amb subtriangular with rounded apices and convex to straight sides. Inner body poorly to well defined, almost parallel to amb outline. Laesurae extending almost to the margin of intexine. Distal sculpture consisting mainly of verrucae with subordinate grana and coni. Verrucae low, 
rounded, sometimes bearing single minute coni or spinae; usually discrete but locally fused. Irregular secondary folds common.

Dimensions. 80-94 $\mu \mathrm{m}$ (10 specimens).

Previous records. This species has been recorded from Lower Carboniferous sequences of the northern hemisphere and Northern and Western Gondwana (see Playford et al., 2001, Melo \& Loboziak, 2003).

\section{Spelaeotriletes colombianus Dueñas \&} Césari sp. nov.

(Figs. 4 B- E)

Synonymy. Spelaeotriletes sp., Dueñas \& Césari 2006, pl. II, fig. 16

Holotype. 2040-2070 (1) C40/2, Fig. 3 B.

Type locality. SM-2 well, Los Llanos Orientales Basin, Colombia.

Diagnosis. Spores radial, trilete, cavate, with convexly subtriangular amb. Laesurae almost straight, usually distinct, with narrow lips or exinal folds that extend to equator. Exoexine slightly thickened at the equatorial margin, laevigate on the contact faces and sculptured on distal and equatorial areas. Sculpture of densely distributed small galeae, coni and grana 1-2 $\mu \mathrm{m}$ broad at base, 1-2 $\mu \mathrm{m}$ high; elements usually discrete or connected basally to form short, irregular narrow ridges. Intexine laevigate, forming a distinct mesospore usually $50 \%$ of the total diameter, with outline in polar view normally conformable with the amb.

Dimensions. 85-103 $\mu \mathrm{m}$ (20 specimens).

Comparisons. According to the detailed revision of Playford et al. (2001) of some different species of Spelaeotriletes our specimens are distinguishable from the Spelaeotriletes triangulus/ Spelaeotriletes arenaceus complex by having diminute, mostly apiculate sculpture of galeae, grana and coni usually discrete, and a slightly thicker exine at the equatorial margin forming a characteristically narrow dark area. According to Playford et al. (2001) and Neves \& Owens (1966), S. triangulus Neves \& Owens displays distal verrucae, coni and galeae, up to $4 \mu \mathrm{m}$ broad and $3.5 \mu \mathrm{m}$ high, regularly distributed and closed spaced that may constitute a reticulum imperfectum. S. arenaceus Neves \& Owens is characterized by irregularly distributed verrucae, coni, bacula and pila, up to $2.5 \mu \mathrm{m}$ broad and $2 \mu \mathrm{m}$ high. The new species is considered segregated of both, $S$. triangulus and $S$. arenaceus type materials, although may be regarded as identical to some Early Carboniferous Amazonian specimens referred to the complex (Melo, pers. comm.). Spelaeotriletes ybertii (Marques Toigo) Playford
\& Powis emend. Playford et al. 1991, is a distinct form having mostly apiculate sculptural elements like bacula and galeae, usually longer than wide and coalescent in short ridges.

\section{CONCLUSIONS}

The palynological assemblages of the SM-4 well, located in the perigondwanic region, provided the only evidence for Early Carboniferous sedimentation in the Colombian Llanos Orientales Basin. The palynofloras contain stratigraphically significant species, including those with Euramerican affinity and those with Gondwanan previous records. As it was pointed out by Dueñas \& Césari (in press), the true distribution of the species throughout the sequence is obscured by caving and reworking, but characteristic Viséan species such as Indotriradites morphon, Anapiculatisporites concinnus and Prolycospora rugulosa were identified only above $2250 \mathrm{ft}$. The stratigraphic interval was referred to the Tournaisian-Viséan by Dueñas \& Césari (in press). Certainly, future studies in other sequences of the Llanos Orientales Basin will improve the knowledge on the biostratigraphic range of the Colombian assemblages.

\section{ACKNOWLEDGEMENTS}

Our thanks to Dr J. H. Melo for his constructive comments as reviewer, to Dr G. Playford by his valuable opinion about some specific identifications and to Dr B. Owens by the reading of an early version of the manuscript. This is a contribution to the IGCP Project 471.

\section{BIBLIOGRAPHY}

Allen, K. C. 1965. Lower and Middle Devonian Spores of North and Central Vestspitsbergen. Palaeontology 8: 687-748.

Bertelsen, F. 1978. A Lower Carboniferous microflora from the Orslev No. 1 borehole, Island of Falster, Denmark. Danmarks Geol. Unders. 2, Raeck. 99: 1-78.

Butterworth, M. A. \& E. Spinner. 1967. Lower Carbonfierous spores from north-west England. Palaeontology 10: 1-24.

Byvsheva, T. V. 1980. Zonal spores assemblages from upper Tournaisian deposits of eastern districts of the Russian Plate; in Palynological Research in Proterozoic and Phanerozoic Oil and Gas Bearing Regions of the USSR, T.V. Byscheva (ed.); Trudy Vsesoiuznogo Nauchno-Issledovatel'skogo Geologoraz-vedochnogo Neftianogo Institut (VNIGRI) 217:53-61 (In Russian).

1985. Spores from deposits of the Tournaisian and Viséan stages of the Russian Plate; in Atlas of 
Spores and Pollen of Phanerozoic Oil and Gas-Bearing strata of the Russian and Turanian Plates, V.V. Menner and T. V. Byvscheva (eds.); Trudy Vsesoiuznogo Nauchno-Issledovatel'skogo Geologorazvedochnogo Neftianogo Instituta (VNIGRI), 253: 80-158 (In Russian).

Clayton, G., R. Coquel, J. Doubinger, K. J. Gueinn, S. Loboziak, B. Owens \& M. Streel. 1977. Carboniferous miospores of Western Europe: illustration and zonation. Meded. Rijks. Geol. Dienst. 29: 1-71.

Clayton, G., I. S. Johnston, G. D. Sevastopulo \& D. G. Smith. 1980. Micropalaeontology of a Courceyan (Carboniferous) borehole section from Ballyvergin, County Clare, Ireland. J. Earth Sc., R. Dubl. Soc. 3: 81-100.

Daemon, R. F. 1974. Palinomorfos-guias do Devoniano Superior e Carbonífero Inferior das bacias do Amazonas e Parnaíba. Ann. Acad. Brasil. Cs. 46: 549-587.

Dueñas, H. \& S. N. Césari. 2003. Primer registro palinológico del Carbonífero Inferior en la Cuenca de los Llanos Orientales de Colombia. Ameghiniana, Supl. 40: 20-21.

- (in press). Palynological evidence of Early Carboniferous sedimentation in the Llanos Orientales Basin, Colombia. Rev. Palaeob. Palyn.

Hacquebard, P. A. 1957. Plants spores in coal from the Horton Group (Mississippian) of Nova Scotia. Micropaleontology 3: 301-324.

Higgs, K. 1975. Upper Devonian and Lower Carboniferous miospore assemblage from Hook Head, County Wexford, Ireland. Micropaleontology 21: 393-419.

Higgs, K., G. Clayton \& J. B. Keegan. 1988. Stratigraphic and systematic palynology of the Tournaisian rocks of Ireland. Geol. Surv. Ireland Sp. Pap. 7, 93 pp.

Higgs, V. I., S. Avkhimovitch, N. Loboziak, M. MazianeSerraj, Stempien-Salek \& M. Streel. 2000. Systematic study and stratigraphic correlation of the Grandispora complex in the Famennian of northwest and eastern Europe. Rev. Palaeobot. Palynol. 112: 207-228.

Hoffmeister, W. S., F. L. Staplin \& R. E. Malloy. 1955. Mississipian plant spores from the Hardinsburg Formation of Illinois and Kentucky. J. Palaeont. 29: 372-399.

Kosanke, R. M. 1950. Pennsylvanian spores of Illinois and their use in correlation. Bull. Geol. Surv. 74: $1-28$.

Lanzoni, E. \& L. Magloire. 1969. Associations palynologiques et leurs applications stratigraphiques dans le Dévonien supérieur et Carbonifère inférieur du Grand Erg Occidental. A scheme of miospore zones for the British (Sahara algérien). Rev. Inst. Fr. Pétrole 23 (4): 441-465.

Loboziak, S., J. H. G. Melo, G. Playford \& M. Streel. 1999. The Indotriradites dolianitti Morphon, a distinct group of miospore species from the Lower Carboniferous of Gondwana. Rev. Palaeobot. Palynol. 107: 17-22.

Luber, A. A. \& I. E. Waltz. 1938. Classification and stratigraphic value of some Carboniferous coal deposits in U.S.S.R., Trudy tsent. nauchno-issled. Geologo-razv. Inst. 105, 45pp. (In Russian).
Massa, D., R. Coquel, S. Loboziak, \& J. TaugourdeauLantz. 1980. Essai de synthèse stratigraphique et palynologique du Carbonifère en Libye occidentale. Ann. Soc. Géol. Nord 99: 429-442.

Melo, J. H. G. \& S. Loboziak. 2003. Devonian-Early Carboniferous miospore biostratigraphy of the Amazon Basin, Northern Brazil. Rev. Palaeobot. Palynol. 124: 131-202.

Naumova, S. N. 1953. Spore-pollen complexes of Upper Devonian of the Russian Plattform and their significance for stratigraphy. Trans. Instit. Geol. Sc., Acad. Sc., USSR, Rel. 143, Geol. Ser. 60: 1-202.

Neves, R., R. J. Gueinn, G. Clayton, N. S. Ioannides, R. S. W. Neville \& K. Kruszewska. 1973. Palynological correlations within the Lower Carboniferous of Scotland and northern England. Trans. Roy. Soc. Edinb. 69: 23-70.

Neves, R. \& B. Owens. 1966. Some Namurian camerate miospores from the English Pennines. Pollen et Spores 8: 337-360.

Owens, B. 1983. Bascaudaspora gen. nov., a new reticulate miospore genus from the Namurian of Northern England. Rep. Inst. Geol. Sc. 83 (10): 4549.

Philips, W. E. A. \& G. Clayton. 1980. The Dinantian clastic succession of Clare Island, County Mayo. $J$. Earth Sci. R. Dubl. Soc. 2: 115-135.

Playford, G. 1962. Lower Carboniferous microfloras of Spitsbergen. Part I. Palaeontology 5: 550-618.

1963. Lower Carboniferous microfloras of Spitsbergen. Part II. Palaeontology 5: 619-678.

- 1964. Miospores from the Mississippian Horton Group, Eastern Canada. Geol. Surv. Canada Bull. 107: $47 \mathrm{pp}$.

- 1976. Plant microfossils from the Upper Devonian and Lower Carboniferous of the canning Basin, northwestern Australia. Paleontographica B, 158: $1-71$.

- 1978. Lower Carboniferous spores from the Ducabrook Formation, Drummond Basin, Queensland. Palaeontographica B, 167: 105-160.

- 1985. Palynology of the Australian Lower Carboniferous a review. C. R. 10th Internat. Cong. Carb. Strat. and Geol., Madrid, 1983, 4: 247-265.

- 1991. Australian Lower Carboniferous miospores relevant to extra-gondwanic correlations: an evaluation. Cour. Forsch.-Inst. Senckenberg, 130: 85-125.

Playford, G., R. Dino \& M. Marques-Toigo. 2001. The upper Palaeozoic miospore genus Spelaeotriletes Neves and Owens, 1966, and constituent Gondwanan species. J. South Amer. Earth Sc, 14: 593-608.

Playford, G. \& D. C. Mc Gregor. 1993. Miospores and organic-walled microphytoplankton of DevonianCarboniferous boundary beds (Bakken Formation), Southern Saskatchewan: a systematic and stratigraphic appraisal. Geol. Surv. Can. Bull. 445: 1-64.

Playford, G. \& D. F. Satterthwait. 1988. Lower Carboniferous (Viséan) spores of the Bonaparte Gulf Basin, northwestern Australia: part three. Palaeontographica B 208: 1-26.

Ravn, R. L. 1991. Miospores of the Kekiktuk Formation (Lower Carboniferous), Endicott Field Area, Alaska North Slope. AASP Contr. Ser. 27: 1-115. 
Ravn, R. L., B. Mc Philemy, M. Rutherford, S. Talli \& G. Bahra. 1994. Late Devonian and Early Carboniferous palynostratigraphy and its applications in northeastern Syria. In: Simmons, M.D. (ed.), Micropalaeontology and Hydrocarbon Exploration in the Middle East, Chapman and Hall, London, pp. 5-21.

Sabry, H. \& R. Neves. 1971. Palynological evidence concerning the unconformable Carboniferous basal measures in the Sanquhar Coalfield, Dumfriesshire, Scotland. C. R. $6^{\text {th }}$ Cong. Int. Carb. Strat. Geol. Sheffield 1967, 4: 1441-1458.

Smith, A. H. V. \& M. A. Butterworth. 1967. Miospores in the coal seams of the Carboniferous of Great Britain. Spec. Pap. Palaeont., 1, 324pp.

Staplin, F. I. \& J. Jansonius 1964. Elucidation of some Paleozoic densospores. Palaeontographica B 114: 95-117.

Streel, M. \& A. Traverse. 1978. Spores from the Devonian/Mississippian transition near the Horseshoe Curve section, Alttona, Pennsylvania, U.S.A. Rev. Palaeobot. Palynol. 26: 21-39.

Sullivan, H. J. 1964. Miospores from the Lower Limestone Shales (Tournaisian) of the Forest of Dean
Basin, Gloucestershire. C. R. 5me.Congr. Avanc. Etud. Stratigr. Carb. (1963) 3: 1249-1258.

- 1968. A Tournaisian spore flora from the Cementstone Group of Ayreshire, Scotland. Palaeontology 11(1): 116-131.

Sullivan, H. J. \& A. E. Marshall. 1966. Viséan spores from Scotland. Micropaleontology 12: 265-285.

Turnau, E. 1978. Spore zonation of uppermost Devonian and Lower Carboniferous deposits of Western Pomerania (N. Poland). Meded. Rijks. Geol. Dienst. 30: 1-35.

Turnau, E., V. L. Avchimovitch, T. V. Byvscheva, G. Clayton, K. T. Higgs \& B. Owens. 1994. Taxonomy and stratigrahical distribution of Verrucosisporites nitidus Playford, 1964 and related species. Rev. Palaeobot. Palynol. 81: 289-295.

Utting, J. 1987. Palynostratigraphic investigation of the Albert Formation (Lower Carboniferous) of New Brunswick, Canada. Palynology 11: 73-96.

Van der Zwan, C. J. 1980. Aspects of Late Devonian and Early Carboniferous palynology of Southern Ireland. III. Palynology of Devonian-Carboniferous transition sequences with special reference to the Bantry Bay area, Co. Cork. Rev. Palaeobot. Paynol. 30: 133-155. 